\title{
Conservation State of Two Paintings in the Santa Margherita Cliff Cave: Role of the Environment and of the Microbial Community
}

francesco armetta ( $\nabla$ francesco.armetta.ch@gmail.com )

Universita degli Studi di Palermo Dipartimento di Scienze e Tecnologie Biologiche Chimiche e Farmaceutiche https://orcid.org/0000-0002-7677-602X

Josue Cardenas

freelance

\section{Eugenio Caponetti}

Universita degli Studi di Palermo Dipartimento di Scienze e Tecnologie Biologiche Chimiche e Farmaceutiche

\section{Rosa Alduina}

Universita degli Studi di Palermo Dipartimento di Scienze e Tecnologie Biologiche Chimiche e Farmaceutiche

\section{Alessandro Presentato}

Universita degli Studi di Palermo Dipartimento di Scienze e Tecnologie Biologiche Chimiche e Farmaceutiche

\section{Luca Vecchioni}

Universita degli Studi di Palermo Dipartimento di Scienze e Tecnologie Biologiche Chimiche e Farmaceutiche

\section{Pietro di Stefano}

Universita degli Studi di Palermo Dipartimento di Scienze della Terra e del Mare

\section{Alberto Spinella}

ATeN Center University of Palermo

\section{Maria Luisa Saladino}

Universita degli Studi di Palermo Dipartimento di Scienze e Tecnologie Biologiche Chimiche e Farmaceutiche

\section{Research Article}

Keywords: cave painting, sulphates and chlorides, bacterial community, environmental monitoring, conservation plan

Posted Date: March 9th, 2021 
DOI: https://doi.org/10.21203/rs.3.rs-222215/v1

License: (c) (1) This work is licensed under a Creative Commons Attribution 4.0 International License. Read Full License

Version of Record: A version of this preprint was published at Environmental Science and Pollution Research on November 9th, 2021. See the published version at https://doi.org/10.1007/s11356-02117211-0. 


\section{Abstract}

The conservation of ancient paintings sited in humid environments is an actual challenge for restorers, because it needs the knowledge of the materials the paintings are made up and of their interaction with a peculiar surrounding environment; thus, tailored procedures and strategies aimed at restoring and preserving paintings are necessary. The Santa Margherita's cave in Castellammare del Golfo (Trapani, Italy) is a natural cave, containing the remains of paintings, in a poor state of conservation, belonging to an ancient church dated back to the Middle Age. The present manuscript reports the monitoring of environmental conditions (i.e., temperature and humidity) in a full year as well as a study on the materials constituting the stone support and the paintings together with a survey of the microbial community. The findings allow us to define the causes which mainly involve the degradation of the paintings. In detail, the degradation of the east and the west wall occurred differently because of the exposure to the sea aerosol, which influenced the salt composition, also contributing to diversifying the bacterial community. Some specific actions to plan the conservation and restoration of paintings and to preserve the site are suggested.

\section{Introduction}

Since prehistory, caves have represented natural shelters for both animals and human beings, featuring traces of their activities that need to be preserved as a potential source of information inherited by modern society. Occasionally, caves could be artificially modified by either building defence walls or decorating them with paintings, depending on the cave's use (Aubert et al. 2018). In the case of shrines or churches, there are plenty of sites which contain paintings of high artistic relevance (Metin and Soslu 2018; Tascon et al. 2017). From a geological perspective, Sicilian territory is characterized by karst landforms (typically featuring underground quarries), therefore composed of sedimentary layers (i.e., cutters, sinks, and caves), resulting from geomorphic processes due to the chemical solubility of rocks in both ground and surface water. Due to high religious influences during the medieval age, several Sicilian caves have been used as churches such as Grotta di Santa Margherita, Parpadura sanctuary, Grotta dei Santi, Grotta del Crocifisso, Grotta di Santa Rosalia, and Grotta di San Mauro to name a few. In many cases, these environmental settings feature the presence of precious paintings, as evidence of the piety and arts in the territory, and especially for small regions, these works of art represent a great economical source and cultural identification. The conservation of ancient paintings sited in humid environments is a continuous challenge because of the different nature and heterogeneity of materials to be preserved. Therefore, it is crucial to deepen the knowledge about the processes involving deterioration and surface modification of such materials. Several studies reported on analyses of paintings to get information about their production and conservation state (Russ et al. 2017; Creer and Kopper 1974; La Russa et al. 2016; Vettori et al. 2016) or determination of biological growth responsible biodeterioration (Caneva et al. 2019; Zhang et al. 2019; Piacenza et al. 2020); others demonstrated the importance of environmental monitoring and the study of processes involved during the decay of different kind of materials (lee, H. S. et al. 2019; Nason and Lithgow 1999; Scatigno et al. 2016; Belfiore et al. 2013). In this study, both 
physical-chemical and biological approaches have been applied at the same time, together with the environmental monitoring, to get a wide view of the system under investigation. This is an important step in view of the restoration or preservation of the painting as well as the site. In this study, physicalchemical and biological approaches allowed to gain valuable information about materials constituting the stone support and paintings of the Santa Margherita's cave in Castellammare del Golfo (Trapani, Italy), as well as to survey for the bacterial community present on the east and west walls of this natural environment. Besides, a full year monitoring of the environmental conditions (i.e., temperature and humidity) of the cave contributed to unveil processes involving degradation phenomena. Thus, based on the information gathered at the multidisciplinary level, the goal of the investigation is to define the conservation state of the paintings and to plan restoration actions aimed to preserve both wall paintings and the site.

\section{The Site}

The Santa Margherita's cave is a karstic cave probably overprinted by marine erosion during Pleistocene times, being located on a coastal cliff in front of the sea (coordinates, Latitude: 38.036601 and Longitude: 12.871712) at an altitude of $10 \mathrm{~m}$ above the sea level. This cave represents an ideal case study evaluating parameters involving degradation processes of the wall painting, as the presence of salts is one of the main causes of deterioration of art objects featuring a porous nature, particularly wall paintings and stone statues (Charola 2000).

According to the description of Galante (Galante 2011), the paintings correspond to the Byzantine style from the XII Century (Purpura 1999), being located in both east and west walls and featuring a different degree (Fig. 1).

The original east wall painting was ca. 27 square meters in size, while the remains extend only for 9 square meters towards the entrance of the cave. Although most of the wall painting is lost, it is clear to see on a frame of 0.40 square meters the representation of Christ's crucifixion. The elements show the right side of a human body with an arm over a cross and a feminine figure with her hands clasped to the chest. The rest of the materials show lines and traces of pigments in different colours. The original painting of West Wall covered a total dimension up to 36 square meters, yet the remains have been reduced to an area of 22 square meters towards the entrance of the cave. On this wall, a new layer of painting overlaps the older one. Details of the two paint layers are reported on Fig. 2. Details of alterations founded in the cave such as lichens, plants, water filtrations, graffitis, fissures on mortars, and looseness of the original mortar are present in Figure S1 of Support Information.

\section{Methods}

\section{Microsampling.}


The analyses of the wall paintings were performed following the principle of minimal invasiveness. Therefore, microsampling the stone support, mortars and plasters was performed. Specifically, 4 samples of stone support (two for each wall) and 3 samples of mortars with parts of the pictorial layer were collected (Fig. 2) (one sample from the east wall and two sets of mortar samples were collected from the two layers of west wall paintings). The samples were named with the first letter $E$ or $W$ if coming respectively from the East or West wall followed by a letter representing the type of material ( $S$ for Stone and $\mathrm{M}$ for Mortar). Considering the presence of two painting layers in the west wall the number 1 or 2 was used to identify respectively the below and upper painting.

\section{Characterisation.}

The monitoring of humidity and temperature was performed along one year by placing the EasyLog ELUSB-2 Lascar electronics data loggers on both east and west walls of the cave.

The stone support and mortars were characterised by optical microscopy and X-Ray Diffractometry to investigate the mineralogical distribution and composition. The observations of the thin sections were done by means of a microscope in polarized, transmitted and incident light on a LEITZ LABORLUX® 12 POL with binocular phototubes and automatic digital camera system LEITZ VARIO-ORTHOMAT ${ }^{\circledR}$ adapted and a rotating stage with different magnification objectives. X-ray Diffraction (XRD) patterns were acquired by a Philips PW 1050/39 diffractometer in the Bragg-Brentano geometry using Ni-filtered Cu Ka radiation $(\lambda=1.54056 \AA)$ in the $2 \theta$ range $5-90^{\circ}$ with a step of $0.05^{\circ}$ and continuing time of $5 \mathrm{sec}$ for step. The X-ray generator worked at a power of $40 \mathrm{kV}$ and a current of $30 \mathrm{~mA}$, and the resolution of the instrument (divergent and antiscatter slits of $0.5^{\circ}$ ) was determined using R-SiO2 and R-Al2O3 standards free from the effect of reduced crystallite size and lattice defects. The phase identification was performed by using the X'pert HighScore ${ }^{\circledR}$ Software and compared with spectra from the database of the RRUFFTM Project.

The constituents of the paintings (pigments, inerts and bindings) were identified by X-ray Fluorescence (XRF), (pigments and inerts) and by IR and NMR Spectroscopy (bindings). The XRF measurements were performed in situ by placing a portable spectrometer Tracer III SD Bruker AXS in contact with the selected coloured area of the painting. The source is a Rhodium Target X-Ray tube operating at $40 \mathrm{kV}$ and $11 \mathrm{~mA}$ and an acquisition time of 30 seconds. The detector is a $10 \mathrm{~mm} 2$ silicon drift X-Flash with Peltier cooling system and a resolution of $145 \mathrm{eV}$ at $100,000 \mathrm{cps}$. The S1PXRF® Software manages data acquisition. The spectral assignments of the characteristic peaks of an element was carried out using the database contained in the ARTAX 8 software. In each spectrum, the signals of Rhodium (Rh) and Argon (Ar) due to the source and the atmosphere, respectively, are present. The net area percentages of the identified elements were obtained by deconvolution of the peaks after background subtraction. Two different types of equipment for Attenuated Total Reflectance (ATR) were used to perform Fourier-transform Infrared Spectroscopy (FTIR) measurements. A Bruker Vertex 70 Advanced Research FT-IR Spectrometer equipped with Platinum ATR and diamond crystal was used to analyse samples in the $70-4000 \mathrm{~cm}^{-1}$ range, with a 
step of $2 \mathrm{~cm}^{-1}$, the measurements have been performed with 200 scans at $2 \mathrm{hPa}$ on a small amount of powdered sample. A Bruker Micro FT-IR LUMOS spectrophotometer equipped with a germanium crystal was used to analyse samples in the $600-4000 \mathrm{~cm}^{-1}$ range, with a step of $2 \mathrm{~cm}^{-1}$. The pigment areas were selected by the microscope magnification, the investigated area corresponding to a few hundreds of microns is due to the crystal tip size. Bruker VERTEX was used to analyse powders of mortars and $\mu \mathrm{FTIR}$ Bruker LUMOS to analyse pigments. Once the spectra were collected, the analysis of the spectra was done by comparing the results with a database from Vahur et al (2016) and the investigation of Tortora et al (2016). ${ }^{1} \mathrm{H}$ NMR spectra and ${ }^{1} \mathrm{H}^{13} \mathrm{C} 2 \mathrm{D}$ HSQC were obtained at room temperature using a Bruker Avance II 400 (9.4T) spectrometer operating at $400.15 \mathrm{MHz}$ and $100.62 \mathrm{MHz}$ for the ${ }^{1} \mathrm{H}$ and ${ }^{13} \mathrm{C}$ nuclei respectively. ${ }^{1} \mathrm{H}$ NMR spectra were performed using a $90^{\circ}$ pulse 12.3 us on the proton, a delay time of $5 \mathrm{~s}$

and 128 scans. The HSQC ${ }^{1} \mathrm{H}-{ }^{13} \mathrm{C}$ correlation experiments were acquired via double INEPT transfer using Echo/Antiecho - TPPI gradient selection and decoupling during acquisition, 32 scans for 512 experiments.

In order to recover the organic part of the pigment layer, the sample was subjected to extraction in deuterated acetone by sonication for $45 \mathrm{~min}$. At the end of this operation, the extract was separated from the insoluble portion by filtration through glass wool and placed in a $5 \mathrm{~mm}$ NMR tube.

\section{Determination of bacterial community}

The metagenomic DNA (mDNA) was isolated from microsamples of stones derived from the east and the west walls of the cave, as described elsewhere (Presentato et al. 2020) with some modifications. Briefly, stone materials were soaked in $3 \mathrm{~mL}$ of sterile saline solution $(\mathrm{NaCl} 0.9 \% \mathrm{w} / \mathrm{v})$ and vigorously shaken (600 rpm) at $30^{\circ} \mathrm{C}$ for 2 hours. Afterwards, stone materials were carefully removed and $\mathrm{NaCl}$ solutions centrifuged $(15,000 \mathrm{~g})$ for 30 minutes at room temperature, generating a biomass pellet that was processed through the chloroform-phenol method to isolate the mDNA. The quality of the mDNA was evaluated by NanoDropTM 2000 spectrophotometer (Thermo Scientific, Waltham, MA, USA) and its suitability was tested by amplifying the 16S rRNA using the universal primer pair F1 and R12 (Coy et al. 2014) with the One Taq DNA polymerase (NEB) under the following thermal conditions: (i) initial denaturation temperature of $95^{\circ} \mathrm{C}$ for $5 \mathrm{~min}$, (ii) run of 30 cycles with each cycle consisting of $30 \mathrm{~s}$ at $95^{\circ} \mathrm{C}$ (denaturation), $30 \mathrm{~s}$ at $50^{\circ} \mathrm{C}$ (annealing) and $1 \mathrm{~min}$ at $72^{\circ} \mathrm{C}$ (extension), and (iii) final extension step at $72^{\circ} \mathrm{C}$ for $10 \mathrm{~min}$. The amplification product was visualized by agarose $(1 \% \mathrm{w} / \mathrm{v})$ gel electrophoresis, which showed bands of the expected size (ca. 1500 base pair [bp]; data not shown), therefore highlighting the suitability of the as-extracted mDNA for further analyses. The microbiome sequencing was carried out on the internal fragment (ca. $464 \mathrm{bp}$ and corresponding to V3-V4 regions) of the $16 \mathrm{~S}$ rRNA, which was amplified by using the primer pairs reported elsewhere (Takahashi et al. 2014) and mDNA as a template. The purified polymerase chain reaction products were sequenced by BMR Genomics Srl (Padova, Italy) in one 300 bp paired-end run on an Illumina MiSeq platform. Raw sequences were inferred using DADA2 v.1.8 (Callahan et al. 2016) in order to trim, filter, remove chimeras and to 
denoise all sequences, obtaining amplicon sequence variants (ASV). Taxonomical assignment was performed using the SINA classifier on the latest SILVA dataset available (Pruesse et al. 2012) (https://www.arb-111 silva.de/ngs/). Rarefaction analysis was carried out plotting the number of observed ASVs against the total number of filtered reads for each sample.

\section{Results And Discussion}

\subsection{Environment Monitoring}

The values of humidity and temperature registered along the year together with correspondent dew point from both walls below the same trend (Figure S2 of Support Information), indicate that the exposition to these two parameters affects the two paintings in the same way. The temperature values along the year show the highest variation between September and March with respectively 26 and $14^{\circ} \mathrm{C}$. The humidity values are affected by a similar relative variation; the values vary from 80 to $50 \%$ from summer to winter. The dew point is lower than the temperature one along the year indicating the absence of vapour condensation phenomena. Nevertheless, the localization in front of the sea, the cave keeps quite a constant environment parameter along the year.

\subsection{Stone support and mortars}

East wall microphotographs of stones thin-section from the host rock (Fig. 3a,b). The sample consists of a small amount of calcite together with dolomite phase (Fig. 3) and match to a dolomitized limestone. The carbonate matrix contains fine-grained dolomite crystals and recrystallized bioclasts, probably benthic foraminifer's tests, that appear as small globular grains.

West wall sample (Fig. 3c,d) shows the features of a dolostone. It is composed of a fine to medium crystalline mosaic of dolomite as evidenced by the XRD pattern (Fig. 3e).

This type of dolomite is formed during diagenetic processes when magnesium-rich groundwaters allow the replacement of calcite $\left(\mathrm{CaCO}_{3}\right)$ with dolomite crystals $\mathrm{CaMg}\left(\mathrm{CO}_{3}\right)_{2}$ (Fairbridge 1957). Both analysed stone samples correspond to the same lithological unit and the same diagenetic process. The host rock of the cave belongs to a sedimentary succession of shallow marine carbonates of Late Triassic age described at the beginning of the past century as "Dolomia Principale di Castellammare del Golfo".

East and West 1 Mortars correspond to a matrix of white colour without aggregates distinguishable by naked eye. The thickness of the layer changes on millimetres according to the surfaces of the wall. West 2 Mortar looks constituted by a white matrix with different sizes of aggregates not well rounded and with variable colours, black, grey, and red. The thickness of the layer ranges from $2 \mathrm{~cm}$ or less in different areas of the painting.

The microscopic observation of mortars cross sections reveals that East Mortar (EM, Fig. 4a) consists of a fine-grained matrix constituted by $90 \%$ of binder fraction and $10 \%$ of amorphous and well-rounded aggregates with particles size between $5 \mu \mathrm{m}$ and $500 \mu \mathrm{m}$ with colours varying from white to reddish 
brown. West 1 Mortar (W1M, Fig. 4b) similar to east mortar consists of a fine-grained matrix constituted by $85 \%$ of binder fraction and $15 \%$ of amorphous and rounded aggregates between $5 \mu \mathrm{m}$ and $200 \mu \mathrm{m}$ with colours varying from white to reddish brown. West 2 Mortar (W2M, Fig. 4c) consists of a matrix constituted by $60 \%$ of binder fraction and $40 \%$ of angular and rounded aggregates with particles size between $50 \mu \mathrm{m}$ and up to $2 \mathrm{~mm}$. The colours change from white and grey to reddish brown. W2M is thus different from the two others.

In order to investigate other possible differences and to individuate influences of the environment, the chemical composition was analysed by IR Spectroscopy and XRD.

The FTIR spectra of the three samples (Fig. 5a) show the characteristic bands of calcite $(713,874,1396$ $\mathrm{cm}^{-1}$ ). In addition, the spectra suggest the presence of different compounds based on carbonates (816, $\left.746,295,220 \mathrm{~cm}^{-1}\right)$, sulphates $\left(614,601,81 \mathrm{~cm}^{-1}\right)$ and iron oxides $\left(432,150 \mathrm{~cm}^{-1}\right)$. The XRD patterns (Fig. 5b) show that the mineral phases occurring in all the samples correspond to calcite (C), quartz (Q) and hydromagnesite $(\mathrm{H})$. According to the literature, these components are related as follow, calcite to the binder fraction, quartz to the aggregates fraction and gypsum to the alteration products of the mortars (Carozzi 1960). It is noted that in coastal regions, the atmosphere is enriched with particles that are naturally generated by the action of wind on the seawater. These particles contain ionic species, principally chlorides and sulphates. Thus, probably sulphates penetrate into the inner of the mortars through ionic diffusion (Salvadori et al.2003; Rizzo et al. 2008). The knowledge of the presence of gypsum is very important because it is well known that it influences the mechanical stability of the mortars and its presence requires specific approaches of conservation (Grassi et al. 2007; Carretti et al. 2007; García-Vera et al. 2020; Salvadori et al. 2003).

\subsection{Pigments and binders}

By the observation of the paintings at simple sight, it can be asserted that the application of the pigments was done through thin layers by means of strokes. The use of plane colours and thicker lines are characteristic of the style of the east and west 1 painting.

In the case of the west 2 painting, the style is more developed by the use of veiling and fine lines in order to represent the characters. The pigments were applied directly on a dry plaster, the pigment layer is not homogenous and has thickness less than $70 \mu \mathrm{m}$ approximately (cross-section is reported in Figure S3 of Support Information).

The investigation of the pigments has been performed by XRF technique, analysing 45 area $(2 \times 3 \mathrm{~mm}$ each). The map and the list of the analysed points is reported in the Figure S4 of Support Information. All the spectra present similarities of composition among all of them. The calcium ( $\mathrm{Ca}$ ) is the major component in all the investigated area (60-90\%). In the case of the bright red, dark red and yellow colours, iron $(\mathrm{Fe})$ is the principal component with a content between $15 \%$ and $60 \%$. The arsenic (As) was identified in the red dark pigment with a content up to $1 \%-2 \%$ which could be accountable for the final hue. The major component of green colour is copper $(\mathrm{Cu})$ with $27 \%$. The calcium (Ca) content increases 
up to $80 \%-90 \%$ in the pink and grey colours, while the iron (Fe) content reduces to $8 \%$; no other representative element is present. Finally, the iron ( $\mathrm{Fe}$ ) content is lower to $5 \%$ in the black colour. According to these findings, we can hypothesize that the chromatic palette is based on earth pigments also known as ochre or iron oxides (Helen 2003). As seen directly on the paintings, and as the literature indicates, the final hues were obtained by a mixture of pigments. In the case of the dark red, the presence of arsenic (As) suggests the probable use of Realgar pigment in the mixture. In the case of the pink and grey pigments, the higher content of calcium ( $\mathrm{Ca}$ ) suggests the use of Bianco di San Giovanni or white lime. In the case of the green pigment, it is possible to assert the use of malachite and finally, in the case of the black colour the absence of peculiar XRF signals indicates the use of vegetable carbon as black pigment. The presence of malachite can be associate to the conversion of azurite, which is well note it degrades in presence of humidity (Saunders and Kirby 2004). To summarise, the list of colours, chemical elements, and identified pigments is reported in Table 1.

Table 1

List of colours, chemical elements, and identified pigments.

\begin{tabular}{|lll|}
\hline Colour & Chemical elements & Pigment \\
\hline Bright Red & $\mathrm{Fe}$ & Red ochre \\
\hline Dark Red & $\mathrm{Fe}, \mathrm{As}$ & Red ochre + Realgar \\
\hline Yellow & $\mathrm{Fe}$ & Yellow ochre \\
\hline Pink & $\mathrm{Ca}, \mathrm{Fe}$ & Mixture of lime white \\
\hline Grey & $\mathrm{Ca}, \mathrm{Fe}$ & Mixture of lime white \\
\hline Green & $\mathrm{Cu}$ & Malachite \\
\hline Black & - & Carbon black \\
\hline
\end{tabular}

In addition, it is interesting to notice that XRF investigation highlighted a strong difference in the elements present in the two walls. In detail, the chlorine content of the east wall (average value $2.6 \%$ ) is about three times greater than the west wall (average value $0.8 \%$ ). This difference can be attributed to the highest exposure of the east wall to the marine aerosol, close to the entrance of the cave, and to the resultant deposition of chlorine salts. As well known the interaction of marine aerosol with building materials causes decay processes (Morillas et al. 2020; Comite et al. 2017; Stefanis et al. 2009; Corvo et al. 2010) and considering the type of the paint it is reasonable to think that it is responsible for the stronger decay and resulting bad conservation of the painting of the east wall.

The organic part of the picture layer (binding and varnish) was investigated by Infrared and NMR Spectroscopy. $\mu \mathrm{FT}$-IR spectra (Fig. 6) show the presence of both inorganic and organic compounds. The bands at $1396,874,713 \mathrm{~cm}^{-1}$ are ascribable to the calcite, while the bands at $1624,1105,596 \mathrm{~cm}^{-1}$ to gypsum in agreement with the results obtained for the mortars. In addition, the IR spectrum of the yellow colour show the bands at $3524,3400,3240 \mathrm{~cm}^{-1}$ suggesting the presence of the pigment gold ochre (Tortora et al.2016). The IR spectrum of the dark red colour show bands at 2954, 2918, $2851 \mathrm{~cm}^{-1}$ which 
could be due to the presence of egg yolk binder (Tortora et al. 2016; Vahur et al. 2016); the bands at 1792, $1733,1716 \mathrm{~cm}^{-1}$ could indicate that an oxidation process involving triglycerides of the egg binder took place (Raymond et al. 1993).

The IR spectra of the yellow samples show low intensity bands at the same position previously described.

In order to confirm the presence of egg yolk used as binder, NMR analysis was carried out on the sample collected from the dark red pigment, which had the strongest observable IR bands, to detect cholesterolrelated signals that might demonstrate the presence of egg yolk (Spyros and Anglos 2006; Sofia et al. 2014).

The signals of ${ }^{1} \mathrm{H}$ NMR spectrum (Fig. 7a) at $0.76,0.87$, and $1.01 \mathrm{ppm}$ could be due to the methyl groups of cholesterol. The 2D HSQC experiment shows that the ${ }^{1} \mathrm{H}^{13} \mathrm{C}$ correlation peaks positions (Fig. 7b) confirming the presence of cholesterol in the analysed sample. The presence of this molecule, according to Sofia et al 2014, is justified by the fact that the oxidation process involving the fatty acids in the egg binder does not affect the original carbon skeleton of the cholesterol. The presence of the cholesterol methyl groups confirms the use of egg yolk as binding media for the paintings.

\section{Microbial characterization}

The microbial survey carried out in the Santa Margherita's cave was aimed to evaluate the microbial community harboured by this unique environment on one hand, and on the other hand, to give insights about the possible role of microorganisms as a potential risk for paintings conservation. Similarly to what was previously unveiled in related cave environments (Ma et al. 2015; Portillo et al. 2008; Pavlik et al. 2018; Yasir 2018; Alonso et al. 2019), the bacterial community of both east and west walls was represented by Firmicutes, Proteobacteria, Bacteroidetes, Actinobacteria, Cyanobacteria, and Gammatimonodota phyla (Fig. 8a).

Firmicutes, mostly featured by Bacillaceae and Planococcaceae members, was the most represented bacterial phylum found in both walls, accounting for $57 \%$ (east) and $76 \%$ (west) of the entire microbial community (Fig. 8a), likely due to the capability of these bacterial strains of overcoming the challenge exerted by the abundant minerals such as carbonates $\left(\mathrm{CaCO}_{3}\right)$ and silicates $\left(\mathrm{SiO}_{2}\right)(\mathrm{Laiz}$ et al.2000; Randazzo et al. 2015), which were found in the Santa Margherita's cave. Indeed, bacilli strains such as Bacillus pasteurii, $B$. cereus, B. megaterium (all belonging to the Bacillaceae family), are bacterial members deeply investigated as bioconsolidants of limestone (De Muynck et al. 2013), concrete (Kim et al. 2013; Achal et al. 2011), and plaster (Anne et al. 2010), as result of biotic processes that catalyse the hydrolysis of urea and organic acids (i.e., oxalates and acetates) as carbon and energy sources to support urease activities, which will result in the production of carbonates (Dhami et al. 2014; Dick et al. 2006). Since the bacterial surface is negatively charged, microbial cells can acquire calcium atoms from the surrounding environment, which can precipitate with carbonates forming $\mathrm{CaCO}_{3}$ at the cell surface. 
Here, the egg yolk used as a binder for the dark red pigment might have represented a source of fatty acids to support bacterial survival in an oligotrophic environment and calcite biomineralization, as reported in the case of Bacillus subtilis (Rossi et al. 2006). Moreover, Bacillus strains are also able to elicit oxidation reactions (Lu et al. 2010) to deal with the toxicity derived from iron-containing compounds such as iron oxides (Walujkar et al. 2019) and their hydrated forms (Petrushkova and Lyalikova 1986) used as pigments, therefore reinforcing the presence of these bacterial families as a predominant part of the cave's microbial community, as well as a potential risk for conservation of wall paintings.

Despite the higher relative percentage of Firmicutes in the west wall than the east one, the latter displayed a more heterogeneous microbial composition, as were also present - with a relative percentage abundance ranging from 1 to $2 \%$ (Fig. 8b) - bacterial members belonging to Lachnospiraceae, Paenibacillaceae, Streptococcaceae, Ruminococcaceae, Oscillospiraceae, Acidaminococcaceae, Christanellaceae, and Eubacteriaceae families, which were not found in the microbial community of the west wall. A similar conclusion can be drawn for Bacteroidota, Actinobacteriota, and Gemmatimonodata phyla (Figs. 8a) that, although a minority, were solely present in the east wall. This aspect, alongside the higher percentage abundance of unclassified bacterial species in the east wall (16\%) versus the west one (3\%), might be ascribed to the far more proximity of the former to the external cave environment, easily allowing microbial colonization to occur in this area. Another contributing factor could derive from the high chlorine extent found in the east area of the cave, explaining its high microbial heterogeneity in terms of bacterial families such as Paenibacillaceae, Streptococcaceae, Ruminococcaceae, Cyclobacteriaceae, Rubrobacteriaceae, Sreptomycetaceae, and Sphingomonadaceae in which are included bacterial strains that can moderately tolerate or even thrive under halophilic conditions (Schabereiter-Gurtner et al. 2001; Remmas et al. 2017; Corral et al. 2020; Chen et al. 2010).

It is also worth noting that some of these bacterial families (i.e., Streptococcaceae, Ruminococcaceae, Moraxellaceae, Streptococcaceae, Oxalobacteriaceae, Eubacteriaceae, Sphingomonadaceae, to name a few) are ascribed to the gut microbiota of wildlife (e.g., bat) (Sun et al. 2020; Gaona et al. 2019) that could occasionally use the cave as a shelter, considering that the site entrance is not protected, thus contributing to the microbiota heterogeneity, as well as constituting a potential risk of cave damaging. Thus, microorganisms that can colonize such an environment are likely to be considered as both indigenous and foreign species, which however possess a versatile metabolism, allowing them to thrive under the most disparate nutritional conditions. In this regard, the Proteobacteria phylum mainly inhabited the west area of the cave, reaching a relative abundance of $13 \%$ (Fig. 8a). The Gammaproteobacteria family of Pseudomonadaceae (11\%) (Fig. 8b) was the most prevalent, being completely absent in the east zone, which was overall featured by a scarce presence of the Proteobacteria (1\%) (Fig. 8). A reasonable explanation for such finding might be due to the emphasized oligotrophy of the west area with respect to the east one, thus allowing Gammaproteobacteria to survive exploiting ions present in the rock likely for chemolithotrophic energy production (Schabereiter-Gurtner et al. 2002). Moreover, bacterial members belonging to the Pseudomonadaceae family are peculiarly proficient in forming biofilm on a vast array of surfaces (Harrison et al. 2004), therefore gaining resistance traits to diverse stressors, as those that might derive by the presence of iron oxides, 
carbonates, and silicates. For instance, Pseudomonas aeruginosa has been described as capable of colonizing different types of silicates growing as a biofilm on mineral surfaces (Aouad et al. 2008), concomitantly stimulating iron release, and overcoming iron deficiency by producing iron scavenging molecules known as siderophores (Hersman et al. 2011). Besides, Pseudomonas strains have been described for their ability to precipitate calcite through biomineralization processes mediated by extracellular urease activities (Abdel-Aleem et al. 2019).

\section{Considerations And Conclusions}

This work is an example of multidisciplinary investigation applied to ancient paintings sited in a humid and marine environment. The paintings of the Santa Margherita's cave in Castellammare del Golfo (Trapani, Italy) have been investigated to evaluate the main causes involved in their degradation and to individuate some specific actions to plan their restoration. The environmental monitoring assured that the conditions of temperature and humidity are quite stable during the year.

First of all, despite the long time after the paintings were done, the remains of mortars and pigments demonstrate that the execution technique and materials had good quality. Under the point of view of their conservation, the paintings are in an advanced state of deterioration, especially those in the east wall, and the painting is a complex scenario for its preservation due to the environment of the site.

The paintings were realized at secco by using poor earth pigments and egg yolk as binder, considerably degraded, on a preparation layer of mortar and the stone support made of dolomite.

The microstructure of the mortar samples indicates similarities of raw materials and production of the east and west 1 paintings, in addition it evidences a secondary production of the West 2 painting with a coarser manufacture even if more recent.

The presence of sulphates detected only on the east wall together with the higher content of chlorine revealed a greater exposure of this wall to the sea aerosol which causes the higher degradation of the painting of the east wall.

Due to the high level of damage of the paintings, they require stabilization, firstly, by procedures of consolidation of both plaster and pictorial film, secondly, by repairing the rims of the mortars in all the areas exposed. The presence of gypsum requires a peculiar approaches of conservation for instance by using specific gels for the surface cleaning (Grassi et al. 2007; Carretti et al. 2007; García-Vera et al. 2020; Salvadori et al. 2003) or consolidant approaches such as the Ferroni-Dini or of the barium method (Matteini 2008; Slížková et al. 2015) or the more recent use of nanolime (Rodrigues et al. 2018.)

The study of the microbiome of the east and west walls of the Santa Margherita's cave demonstrated common microbial members, mainly belonging to the Bacillaceae and Planococcaceae families, likely due to their ability of colonizing environments rich of minerals, such as carbonates and silicates (Laiz et al. 2000; Randazzo et al. 2015). In addition, microbiome analysis evidenced differences among the two 
walls, with east wall carrying a higher abundance of Bacteroidota, probably linked with faecal animal contamination due to the close proximity of this wall to the uncontrolled entrance of the cave; contrarily, west wall contained more Proteobacteria, reasonably due to their capability of adaptation to more oligotrophic environments.

All these biotic aspects highlight microorganisms as prone and efficient in colonizing harsh and extreme environments as that represented by the case study here reported; however, considering the biochemical repertoire that bacteria can elicit in response to diverse external stresses, whether microbes can act as deteriogen or biocontrol agents is yet to be defined. Indeed, if DNA sequencing-based technology represents a powerful tool to unveil the identity of uncultivable microbes, further research is needed to deeply understand how physical-chemical and biological aspects of cave environment interplay with each other, therefore improving the development of improved restoration strategies for the conservation of such a complex environmental niche.

The immediate intervention could be a physical barrier, like a gate to put at the entrance of the cave. This could avoid the problem of the presence of insects, birds or bats.

However, the growth of bacteria could be solved, at least for few years, by using controlled release systems (Dresler et al. 2017) which inhibit the bacterial growth. In a previous paper some samples collected at the Santa Margherita cave have been treated and the efficacy of treatment was demonstrated for one year (Presentato et al. 2020).

At the end of the conservation work, a thin layer of protective could be applied as sacrificial layers in order to improve the hydro-repellency of the surface (Caponetti et al. 2021; Renda et al. 2020).

\section{Declarations}

\section{AUTHOR CONTRIBUTIONS}

FA, EC, and MLS: Conceptualization and methodology. JC and FA: XRD, XRF, and FT-IR investigation. PdS: petrographic analysis. RA, AP and LV: biological test, bioinformatic analysis and data analysis. AS: NMR data. FA, EC, MS, RA, and AP: writing-review and editing. All authors contributed to the article and approved the submitted version.

\section{FUNDING}

A.P. and F.A thank MIUR for the Project PON Ricerca e Innovazione 2014-2020 - Avviso DD 407/2018 "AIM Attrazione e Mobilità Internazionale" (AIM1808223). This work is part of the project "Development and Application of Innovative Materials and processes for the diagnosis and restoration of Cultural Heritage-DELIAS"-PONO3PE 002142 (Programma Operativo Nazionale Ricerca e Competitività20072013). 


\section{Acknowledgments}

This work is dedicated to Prof. Sebastiano Tusa's memory for permission to investigate in situ the paintings at Santa Margherita Cave and to collect the samples, wishing that his dream of restauration of the painting does come true.

The authors would like to express our gratitude to Comune di Catellammare del Golfo for the interest to the research. EC, GC and FA thank Mr I. Sottile for useful discussions and guide us to reach the site. Thanks are due to Prof. G. Traina of the Academy of Art of Palermo for his precious suggestions about the methodology to use for the restoration of the paintings.

\section{References}

1. Abdel-Aleem H, Dishisha T, Saafan A et al (2019) Biocementation of soil by calcite/aragonite precipitation using Pseudomonas azotoformans and Citrobacter freundii derived enzymes. https://doi.org/10.1039/C9RA02247C

2. Achal V, Mukherjee A, Reddy M (2011) Effect of calcifying bacteria on permeation properties of concrete structures. J Ind Microbiol Biot 38:1229-1234 10.1007/s10295-010-0901-8

3. Alonso L, Pommier T, Kaufmann B et al (2019) Anthropization level of Lascaux Cave microbiome shown by regional-scale comparisons of pristine and anthropized caves. Molecular Ecology, 28(14):3383-3394. 10.1111/mec.15144

4. Anne S, Rozenbaum O, Andreazza P, Rouet J (2010) Evidence of a bacterial carbonate coating on plaster samples subjected to the calcite bioconcept biomineralization technique. Constr Build Mater 24:1036-1042 10.1016/j.conbuildmat.2009.11.014

5. Aouad G, Crovisier JL, Damidot D et al. (2008) Interactions between municipal solid waste incinerator bottom ash and bacteria (Pseudomonas aeruginosa). Sci Total Environ 393:385-393.

6. Aubert M, Setiawan P, Oktaviana AA, Brumm A et al (2018) V Palaeolithic cave art in Borneo. Nature 564:254-257.

7. Belfiore CM, Barca D, Bonazza A et al. (2013) Application of spectrometric analysis to the identification of pollution sources causing cultural heritage damage. Environ Sci Pollut Res 20:88488859. https://doi.org/10.1007/s11356-013-1810-y

8. Callahan BJ, McMurdie PJ, Rosen MJ et al. (2016) DADA2: high-resolution sample inference from Illumina amplicon data. Nature Methods 13: 581-583. doi:10.1038/nmeth.3869

9. Caneva G, Bartoli F, Fontani M, Mazzeschi D, Visca P (2019) Changes in biodeterioration patterns of mural paintings: Multi-temporal mapping for a preventive conservation strategy in the Crypt of the Original Sin (Matera, Italy). Journal of Cultural Heritage 40:59-68.

10. Caponetti E, Armetta F, Ciaramitaro V et al. (2021) Effectiveness of some protective and self-cleaning treatment: a challenge for the conservation of the Temple $\mathrm{G}$ in Selinunte Progress in surface coating 151:106020 
11. Carozzi V A (1960) Microscopic sedimentary petrography. John Wiley \& sons, Inc., New York and London

12. Carretti E, Giorgi R, Berti D, Baglioni P (2007) Oil-in-water nanocontainers as low environmental impact cleaning tools for works of art: Two case studies Langmuir 23(11):6396-6403

13. Charola AE (2000) Salt in the deterioration of porous materials. J. Am. Inst. Conserv. 39:327-343.

14. Chen Q, Liu Z, Peng Q et al. (2010) Diversity of halophilic and halotolerant bacteria isolated from non-saline soil collected from Xiaoxi National Natural Reserve, Hunan Province. 50(11):1452-9

15. Comite V, Álvarez de Buergo M, Barca D et al (2017) Damage monitoring on carbonate stones: Field exposure tests contributing to pollution impact evaluation in two Italian sites. Construction and Building Materials, 152:907-922, https://doi.org/10.1016/j.conbuildmat.2017.07.048.

16. Corral P, Amoozegar MA, Ventosa A (2020) Halophiles and Their Biomolecules: Recent Advances and Future Applications in Biomedicine. Mar. Drugs 18:33. https://doi.org/10.3390/md18010033

17. Corvo F, Reyes J, Valdes $C$ et al. (2010) Influence of Air Pollution and Humidity on Limestone Materials Degradation in Historical Buildings Located in Cities Under Tropical Coastal Climates. Water Air Soil Pollut 205:359. https://doi.org/10.1007/s11270-009-0081-1

18. Costa EAL, Campos VP, da Silva Filho LCP, Greven HA (2009) Evaluation of the aggressive potential of marine chloride and sulfate salts on mortars applied as renders in the Metropolitan Region of Salvador - Bahia. Brazil J Environ Manage 90:1060-1068

19. Coy MR, Hoffmann M, Kingdom Gibbard HN et al (2014) Nested-quantitative PCR approach with improved sensitivity for the detection of low titer levels of Candidatus Liberibacter asiaticus in the Asian citrus psyllid, Diaphorina citri Kuwayama. J. Microbiol. Methods, 102:15-22, doi:10.1016/j.mimet.2014.04.007.

20. Creer KM, Kopper JS (1974) Paleomagnetic Dating of Cave Paintings in Tito Bustillo Cave, Asturias, Spain. Science 186:348-350

21. De Muynck W, Verbeken K, De Belie N, Verstraete W (2013) Influence of temperature on the effectiveness of a biogenic carbonate surface treatment for limestone conservation App/ Microbiol Biot 97:1335-1347 10.1007/s00253-012-3997-0

22. Dhami NK, Reddy MS, Mukherjee A (2014) Application of calcifying bacteria for remediation of stones and cultural heritages. Front Microbiol 5:304 10.3389/fmicb.2014.003044071612

23. Dick J, De Windt W, De Graef B, Saveyn H, Van DM, De Belie N, Verstraete W (2006) Bio-deposition of a calcium carbonate layer on degraded limestone by Bacillus species. Biodegradation 17:357-367 $10.1007 /$ s10532-005-9006-x

24. Dresler C, Saladino ML, Demirbag C et al. (2017) Development of controlled release systems of biocides for the conservation of cultural heritage International Biodeterioration \& Biodegradation 125:150-156

25. Galante M (2011) La grotta Santa Margherita Ministero dell'Istruzione, dell'Università e della Ricerca Accademia di Belle Arti di Palermo. 
26. Galizzi A, Mastromei G, Rossi M et al (2006) Bacillus subtilis Gene Cluster Involved in Calcium Carbonate Biomineralization Chiara Barabesi, Journal of Bacteriology Dec 189 (1):228-235; DOI: 10.1128/JB.01450-06

27. Gaona O, Cerqueda-Garcl'a D, Falco'n LI et al. (2019) Microbiota composition of the dorsal patch of reproductive male Leptonycteris yerbabuenae. PLoS ONE 14(12):0226239.

https://doi.org/10.1371/journal. pone.0226239

28. García-Vera VE, Tenza-Abril AJ, Solak AM, Lanzón M (2020) Calcium hydroxide nanoparticles coatings applied on cultural heritage materials: Their influence on physical characteristics of earthen plasters Applied Surface Science 504:144195

29. Grassi S, Carretti E, Pecorelli P et al (2007) The conservation of the Vecchietta's wall paintings in the Old Sacristy of Santa Maria della Scala in Siena: The use of nanotechnological cleaning agents Journal of Cultural Heritage, 8(2):119-125

30. Harrison JJ, Ceri H, Stremick C, Turner RJ (2004) Biofilm susceptibility to metal toxicity. Environ Microbiol 6:1220-1227.

31. Helen H (2003) Pigments of English Medieval Wall Painting Archetype publications. London.

32. Hersman LE, Huang A, Maurice PA, Jennifer H (2011) Forsythe Siderophore Production and Iron Reduction by Pseudomonas mendocina in Response to Iron Deprivation. Geomicrobiology Journal, 4:261-273 https://doi.org/10.1080/01490450050192965.

33. Kim HK, Park SJ, Han JI, Lee HK (2013) Microbially mediated calcium carbonate precipitation on normal and lightweight concrete Constr Build Mater 38:1073-1082

10.1016/j.conbuildmat.2012.07.040

34. La Russa MF, Rovella N, Pelosi Cet al (2016) A multi-analytical approach applied to the archaeometric study of mortars from the Forty Martyrs rupestrian complex in Cappadocia (Turkey). Microchemical Journal 125:34-42.

35. Laiz L, Recio D, Hermosin Saiz-Jimenez BC (2000) Microbial communities in salt efflorescences. In Of Microbes and Art, the Role of Microbial Communities in the Degradation and Protection of Cultural Heritage. Kluwer Academic/Plenum Publishers, New York.

36. lee HS, Kim SH, Han KS (2019) Diagnosis and Evaluation of Conservation State of Mural Paintings in Payathonzu Temple on Bagan Heritage Site in Myanmar. Journal of Conservation Science The Korean Society of Conservation Science for Cultural Heritage 35(5):494-507 doi:

10.12654/jcs.2019.35.5.10

37. Lu S et al. (2010) Ecophysiology of Fe-cycling bacteria in acidic sediments. Appl. Environ. Microbiol. 76:8174-8183.

38. Ma Y, Zhang H, Du Y et al (2015) The community distribution of bacteria and fungi on ancient wall paintings of the Mogao Grottoes. Scientific reports, 5:7752. https://doi.org/10.1038/srep07752

39. Matteini, M (2008) Inorganic treatments for the consolidation and protection of stone artefacts. Conservation Science in Cultural Heritage, 8(1):13-27. https://doi.org/10.6092/issn.1973-9494/1393 40. Metin S, Soslu A (2018) The Altıkapılı Cave Church at Pisidia Hüseyin. Adalya 21:311-334. 
41. Morillas H, França de Mendonça Filho F, Derluyn $\mathrm{H}$ et al (2020) Decay processes in buildings close to the sea induced by marine aerosol: Salt depositions inside construction materials, Science of The Total Environment, 721:137687, https://doi.org/10.1016/j.scitotenv.2020.137687.

42. Nason G, Lithgow K (1999) Environmental monitoring of the great painted staircase at Knole, The Conservator, 23:57-67, DOI: 10.1080/01410096.1999.9995139

43. Pavlik I, GersI M, Bartos M et al. (2018) Nontuberculous mycobacteria in the environment of Hranice Abyss, the world's deepest flooded cave (Hranice karst, Czech Republic).Environ Sci Pollut Res 25:23712-23724. https://doi.org/10.1007/s11356-018-2450-z

44. Petrushkova JP, Lyalikova NN (1986) Microbiologial degradation of lead-containing pigments in mural paintings. Stud. Conserv. 31:65-69.

45. Piacenza E, Presentato A, Di Salvo F et al. (2020) A combined physical-chemical and microbiological approach to unveil the fabrication, provenance, and state of conservation of the Kinkarakawa-gami art. Sci. Rep. 10:16072. https://doi.org/10.1038/s41598-020-73226-6

46. Portillo MC, Gonzalez JM, Saiz-Jimenez C. (2008) Metabolically active microbial communities of yellow and grey colonizations on the walls of Altamira Cave, Spain. J Appl Microbiol. Mar; 104(3):681-91. doi: 10.1111/j.1365-2672.2007.03594.x.

47. Presentato A, Armetta F, Spinella A et al. (2020) Formulation of mesoporous silica nanoparticles for controlled release of antimicrobials for stone preventive conservation Frontiers in Chemistry 8:699. Manuscript ID: 555668. doi: 10.3389/fchem.2020.00699

48. Presentato A, Lampis S, Vantini A et al (2020) On the Ability of Perfluorohexane Sulfonate (PFHxS) Bioaccumulation by Two Pseudomonas sp. Strains Isolated from PFAS-Contaminated Environmental Matrices. Microorganisms 8:92.

49. Pruesse E, Peplies J, Glockner FO (2012) SINA: Accurate high-throughput multiple sequence alignment of ribosomal RNA genes. Bioinformatics 28 (14):1823-1829. doi:10.1093/bioinformatics/bts252

50. Purpura G (1999) Le pitture della grotta di Santa Margherita, Kalos - L'arte in Sicilia. Kalos 6:30

51. Randazzo L et al. (2015) Flos Tectorii degradation of mortars: An example of synergistic action between soluble salts and biodeteriogens. J. Cult. Herit. 16:838-847.

52. Raymond J. Meilunas, James G. Bentsen and Arthur Steinberg (1993) Analysis of Aged Paint Binders by FTIR Spectroscopy. Studies in Conservation, 35: 33-51.

53. Remmas N, Melidis P, Voltsi C, Athanasiou D, Ntougias S. (2017) Novel hydrolytic extremely halotolerant alkaliphiles from mature landfill leachate with key involvement in maturation process. $J$ Environ Sci Health A Tox Hazard Subst Environ Eng. 52(1):64-73. doi: 10.1080/10934529.2016.1229931.

54. Renda V, Alvarez de Buergo M, Saladino ML, Caponetti E (2020) Assessment of protection treatments for carbonatic stone using nanocomposite coatings" Progress in Organic Coatings 141:105515

55. Rhodes W F (1957) The dolomite question Regional Aspects of Carbonate Deposition Edited by Rufus J. Le Blanc And Julia G. Breeding 5:125-178. 
56. Rizzo G, Ercoli L, Parlapiano M (2008) Characterization of mortars from ancient and traditional, water supply systems in Sicily. J Therm Anal Calorim 92 (1): 323-330

57. Rodrigues JD, Ferreira Pinto AP, Nogueira R, Gomes A (2018) Consolidation of lime mortars with ethyl silicate, nanolime and barium hydroxide. Effectiveness assessment with microdrilling data Journal of Cultural Heritage 29:43-53

58. Russ J, D Pohl M, L von Nagy C et al (2017) Strategies for 14C Dating the Oxtotitlán Cave Paintings, Guerrero, Mexico. Advances in Archaeological Practice 5:170-183.

59. Salvadori B, Errico V, Mauro M, Melnik E, Dei L (2003) Evaluation of Gypsum and Calcium Oxalates in Deteriorated Mural Paintings by Quantitative FTIR Spectroscopy. Spectroscopy Letters 36(5-6):501513

60. Saunders D, Kirby J (2004) The Effect of Relative Humidity on Artists' Pigments. National Gallery Technical Bulletin 25:62-72

61. Scatigno C, Gaudenzi S, Sammartino MP, Visco G (2016) A microclimate study on hypogea environments of ancient roman building. Science of The Total Environment 566-567, 298-305

62. Schabereiter-Gurtner C, Piñar G, Vybiral D, Lubitz W, Rölleke S (2001) Rubrobacter-related bacteria associ- ated with rosy discolouration of masonry and lime wall paintings. Arch Microbiol. 176(5):347- 354. https://doi.org/10.1007/s002030100333

63. Schabereiter-Gurtner C, Saiz-Jimenez C, Pinar G et al. (2002) Phylogenetic 16S rRNA analysis reveals the presence of complex, partly unknown bacterial communitiesin Ttito bustillo cave, Spain, on its palaeolithic paintings. Environ Microbiol. 4:392-400.

64. Slížková Z, Drdácký M, Viani A (2015) Consolidation of weak lime mortars by means of saturated solution of calcium hydroxide or barium hydroxide. Journal of Cultural Heritage 16(4):452-460

65. Sofia S, Elini K, Anglos D, Spyros A (2014) Egg yolk identification and aging in mixed paint binding media by NMR spectroscopy. John Wiley \& Sons, Ltd

66. Spyros A, Anglos D (2006) Studies of organic paint binders by NMR spectroscopy. Applied Physics A. Materials Science \& Processing. A 83:705-508.

67. Stefanis NA, Theoulakis P, Pilinis C (2009) Dry deposition effect of marine aerosol to the building stone of the medieval city of Rhodes, Greece, Building and Environment, 44(2):260-270

68. Sun DL, Gao YZ, Ge XY, Shi ZL, Zhou NY (2020) Special Features of Bat Microbiota Differ From Those of Terrestrial Mammals. Front. Microbiol. 11:1040. doi: 10.3389/fmicb.2020.01040

69. Takahashi S, Tomita J, Nishioka K, Hisada T, Nishijima M (2014) Development of a prokaryotic universal primer for simultaneous analysis of Bacteria and Archaea using next-generation sequencing. PloS one 9 (8):105592. doi:10.1371/journal.pone.0105592

70. Tascon M, Mastrangelo N, Gallegos D, Marte F (2017) Determination of materials and techniques involved in the mural paintings of San Miguel Church, Argentina. Journal of Raman Spectroscopy 48:1356-1364. 
71. Tortora M, Sfarra S, Chiarini M et al (2016) Non-destructive and micro-invasive testing techniques for characterizing materials, structures and restoration problems in mural paintings. Applied Surface Science. Volume 387: 971-985

72. Vahur S, Teearu A, Peets P, Joosu L, Leito I (2016) ATR-FT-IR spectral collection of conservation materials in the extended region of $4000-80 \mathrm{~cm}^{-1}$. Analytical and Bioanalytical Chemistry 408 : 3373-3379.

73. Vettori S, Bracci S, Cantisani E et al (2016) A multi-analytical approach to investigate the state of conservation of the wall paintings of Insula 104 in Hierapolis (Turkey). Microchemical Journal 128:279-287.

74. Walujkar SA et al. (2019) Utilizing the iron tolerance potential of Bacillus species for biogenic synthesis of magnetite with visible light active catalytic activity. Colloid Surf. B 177: 470-478.

75. Yasir M (2018) Analysis of bacterial communities and characterization of antimicrobial strains from cave microbiota. Braz J Microbiol. 49(2):248-257. doi: 10.1016/j.bjm.2017.08.005.

76. Zhang G, Gong C, Gu J, Katayama Y, Someya T, Gu JD (2019) Biochemical reactions and mechanisms involved in the biodeterioration of stone world cultural heritage under the tropical climate conditions International. Biodeterioration \& Biodegradation 143:10472

\section{Figures}




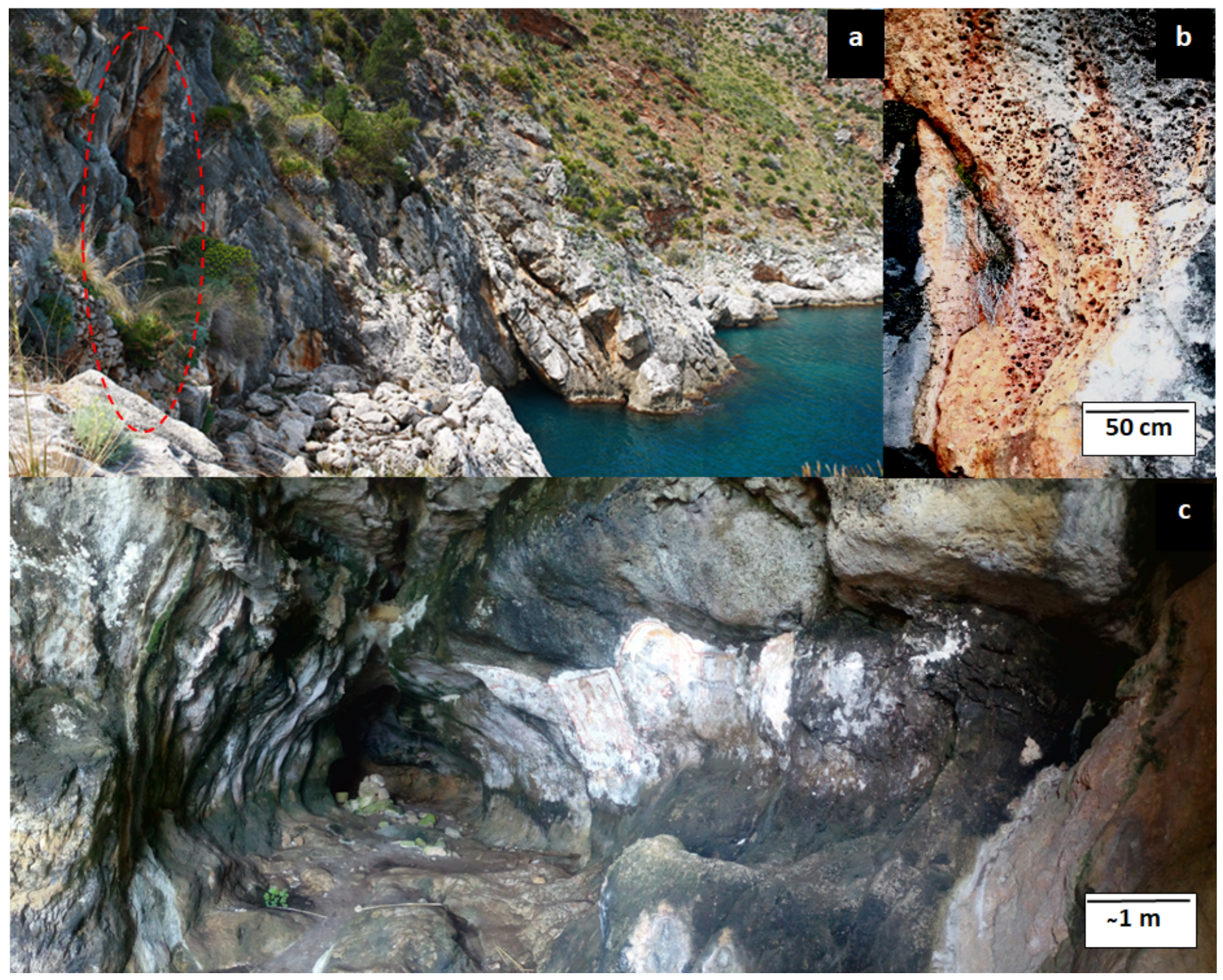

Figure 1

Coastal cliff in which the site is located, the entrance of the cave is indicated by a red circle (a); detail of the cavities on the surface eroded at the entrance of the cave (b); general view of the interior of the cave (c), the eastern wall is to the left side of the picture and the western wall to the right. Note: The designations employed and the presentation of the material on this map do not imply the expression of any opinion whatsoever on the part of Research Square concerning the legal status of any country, territory, city or area or of its authorities, or concerning the delimitation of its frontiers or boundaries. This map has been provided by the authors. 


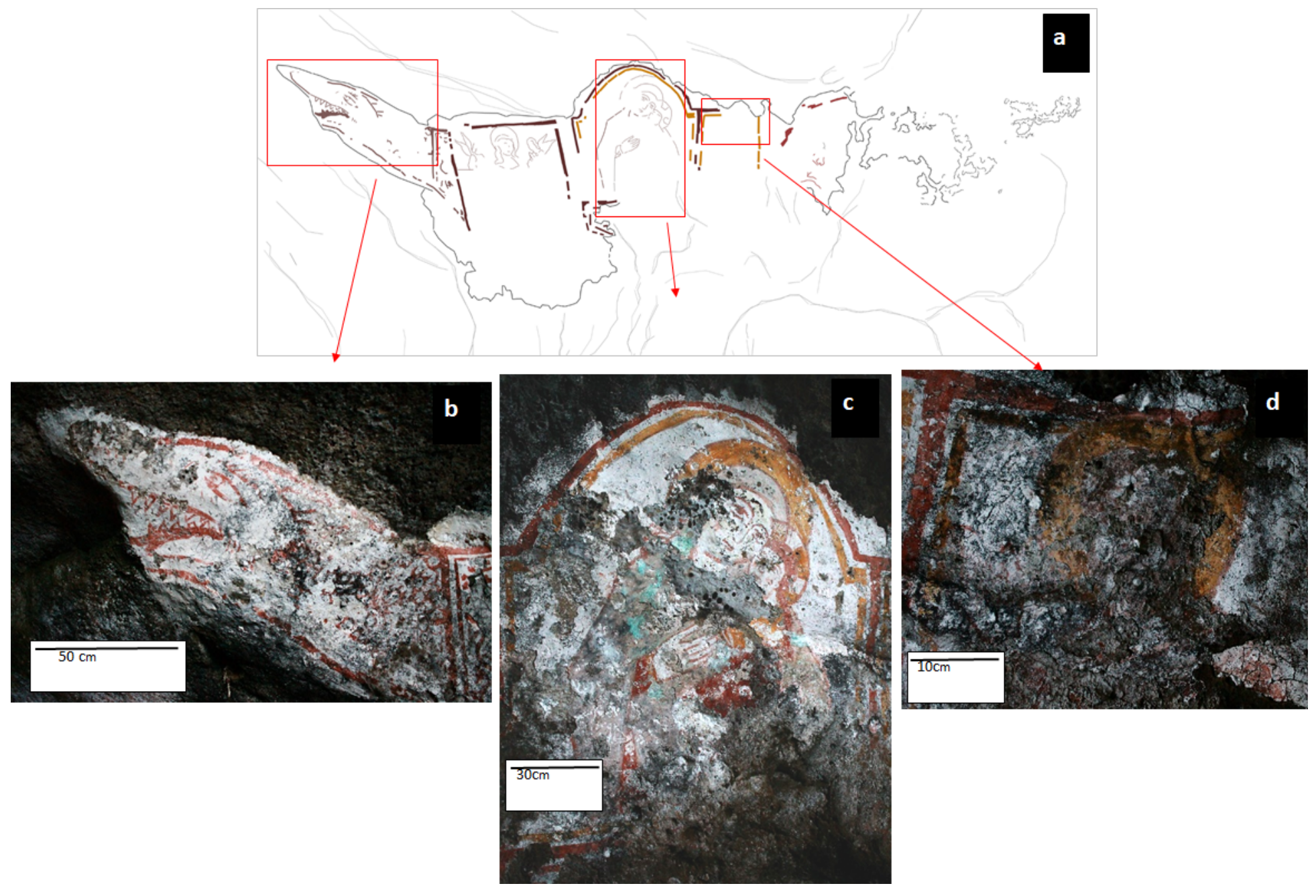

Figure 2

Map (a) and details from the scenes represented on the first layer of painting from the west wall, mostro marino (b), Madonna col bambino (c), figure not identifiable (d). Note: The designations employed and the presentation of the material on this map do not imply the expression of any opinion whatsoever on the part of Research Square concerning the legal status of any country, territory, city or area or of its authorities, or concerning the delimitation of its frontiers or boundaries. This map has been provided by the authors. 

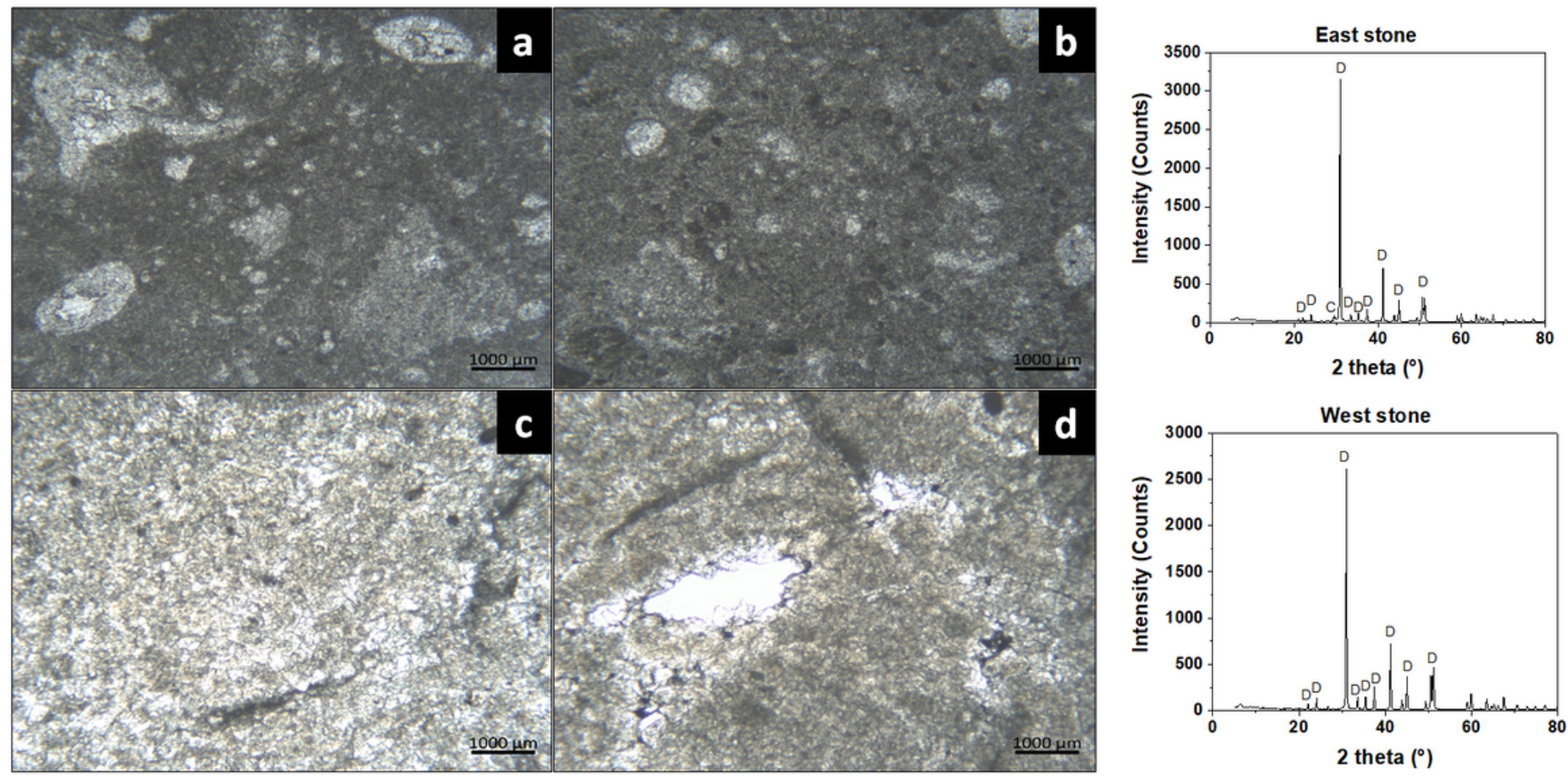

\section{Figure 3}

Microphotographs of the thin sections from east wall (a-b) and west wall (c-d). XRD patterns obtained from samples east and west stone (e). The crystal phases correspond to Dolomite (D) (Ref Code 01-0751655) and Mg Calcite (Ca) (Ref Code 01-086-2335).

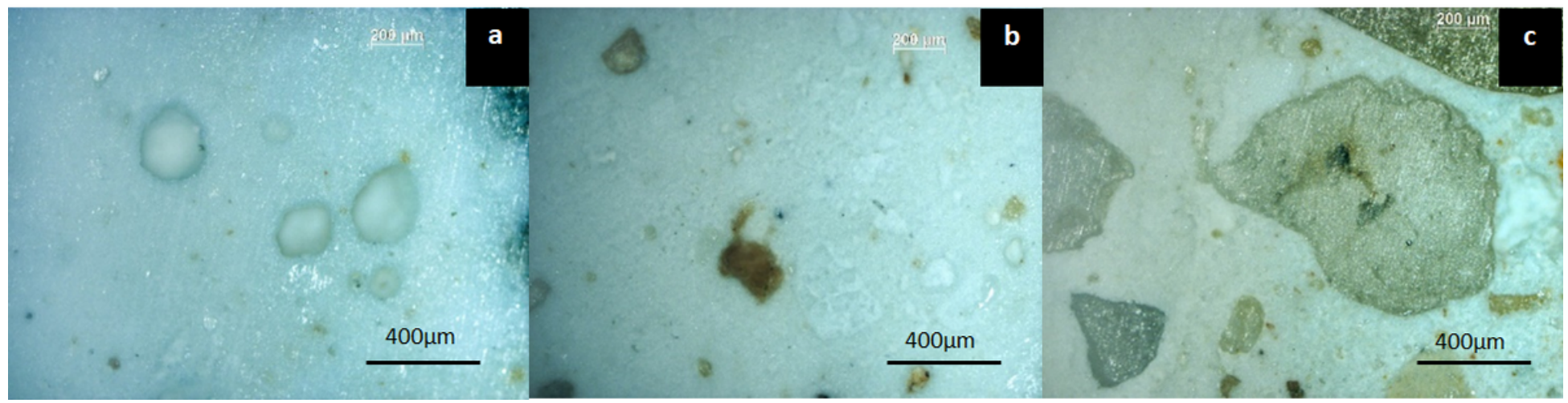

\section{Figure 4}

Photo of samples from East Mortar (a), West 1 Mortar (b) and West 2 Mortar (c) observed under the optical microscope. 

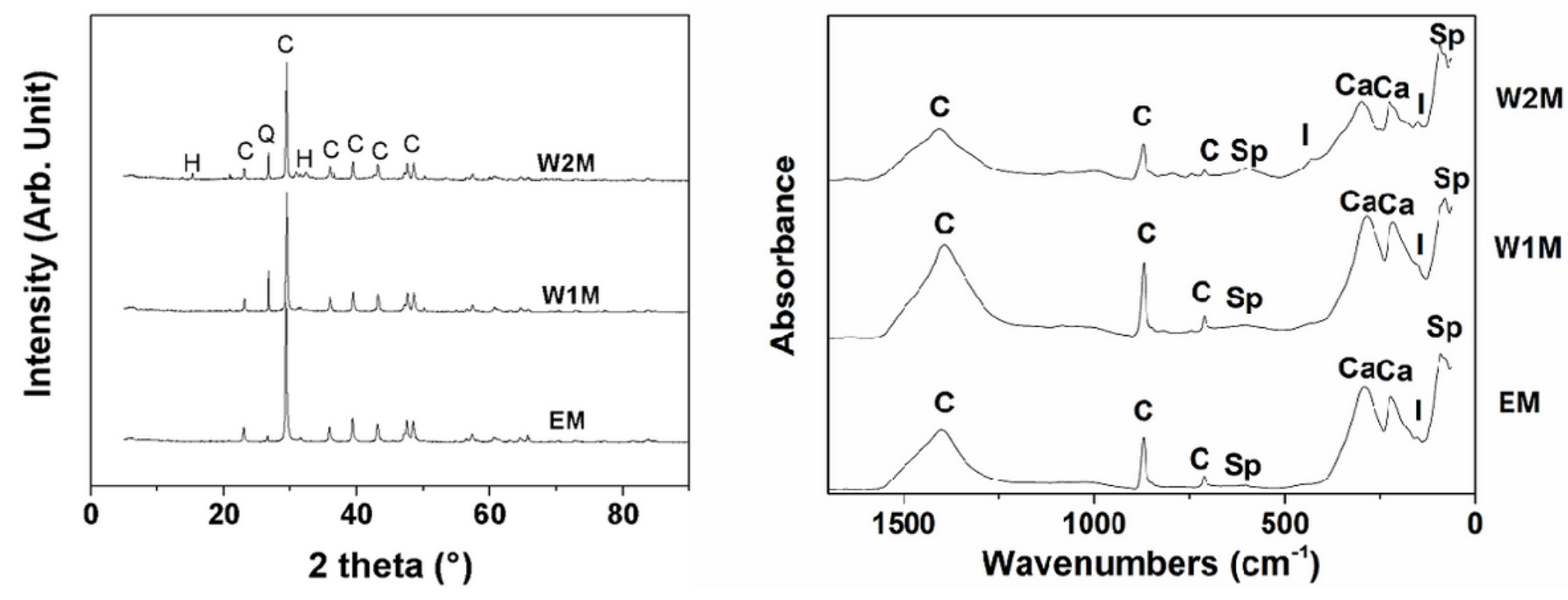

Figure 5

FTIR spectra of east mortar (EM), west 1 mortar (W1M), west 2 mortar (W2M) showing the bands associated to calcite (C), other carbonates (Ca), sulphates (Sp), iron oxides (I). XRD patterns of East Mortar (EM), West Mortar 1 (WM1), West Mortar 2 (WM2). The crystal phases correspond to calcite (C), Hydromagnesite $(\mathrm{H})$ and quartz $(\mathrm{Q})$. 


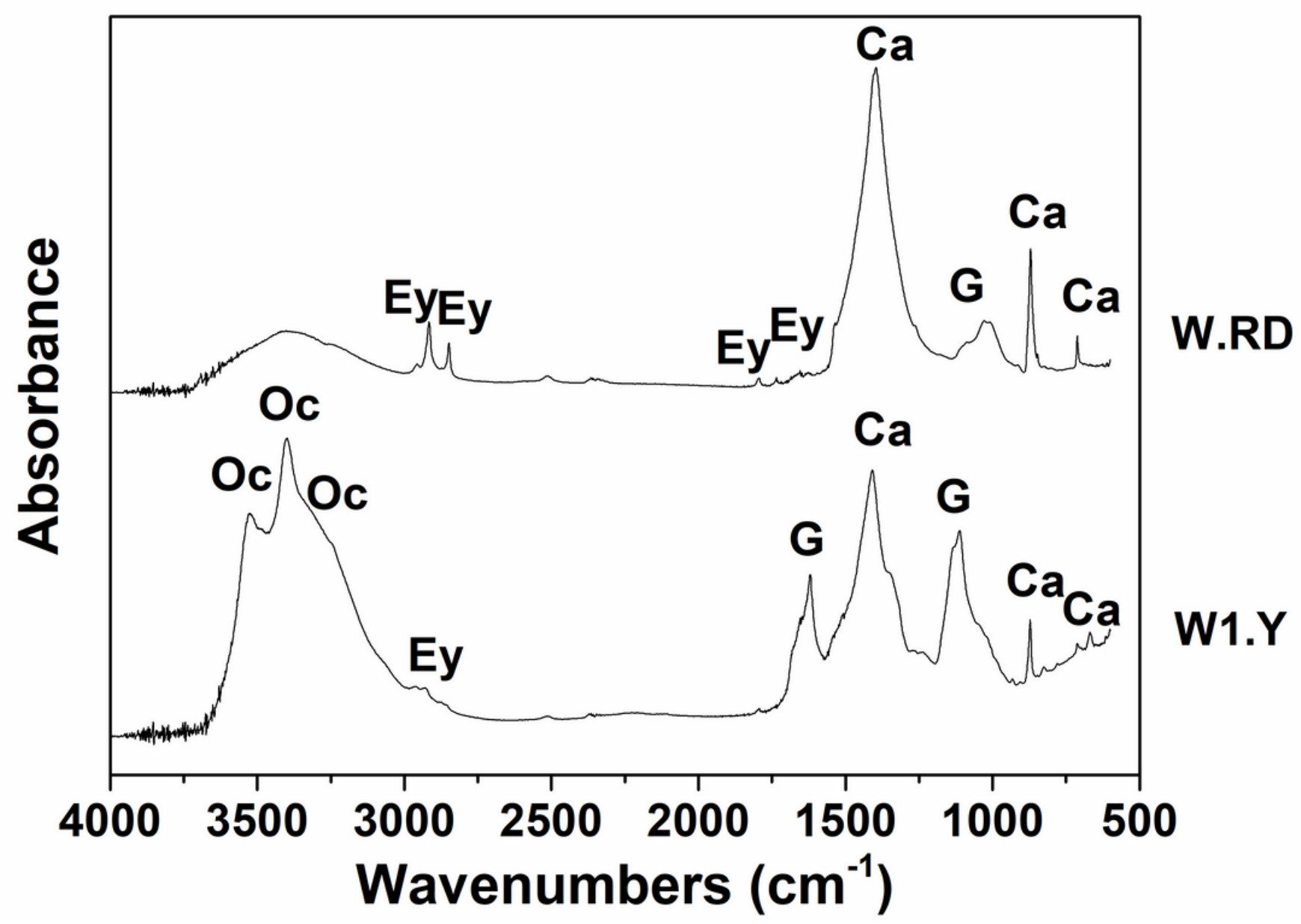

Figure 6

HFTIR spectra of the yellow pigment (W1.Y) from painting 1 and dark red (W.RD) from the West wall. The bands obtained suggest the presence of calcite (Ca), gypsum (G), italian gold ochre pigment (Oc) and egg yolk (Ey).
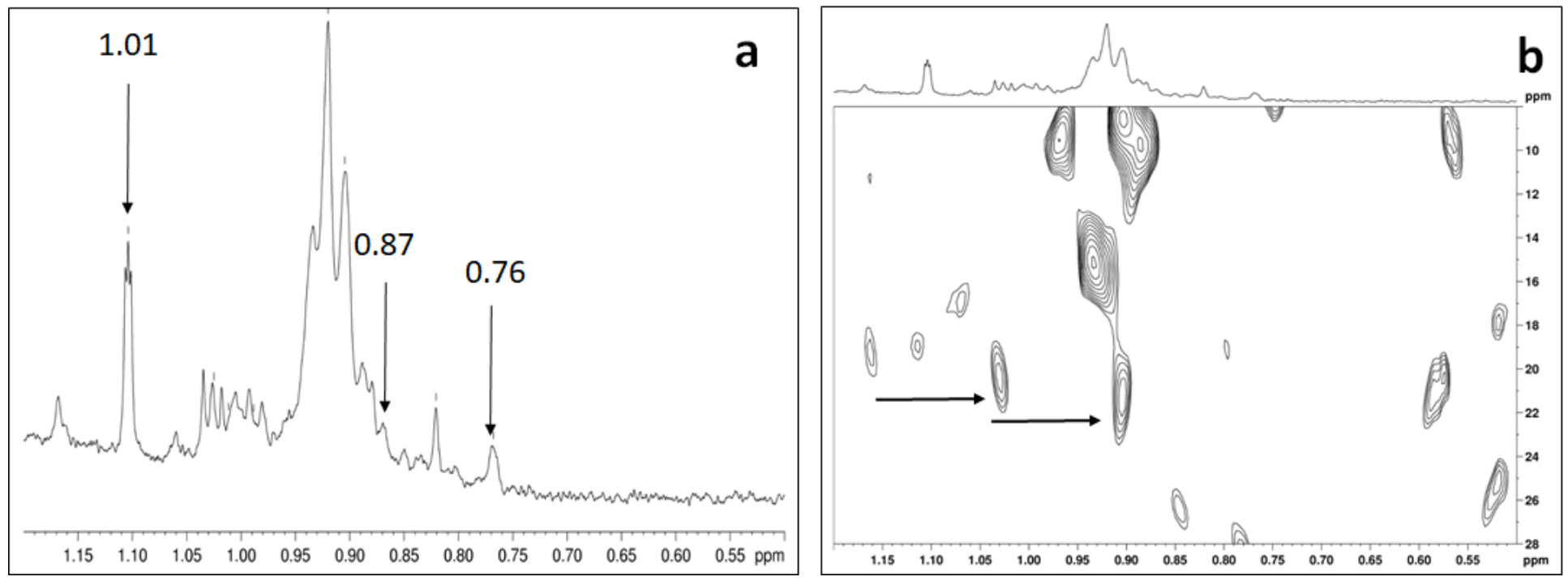


\section{Figure 7}

$1 \mathrm{H}$ NMR spectra in acetone-d6 solution of the dark red pigment at magnetic field strength of $400.15 \mathrm{MHz}$ showing peaks of acetone and methyl groups (a). Aliphatic methyl region of the $400.15 \mathrm{MHz} 1 \mathrm{H} 2 \mathrm{D}$ HSQC NMR spectra of the sample, the arrows indicate the characteristic pattern of the cholesterol methyl groups appearing (b)
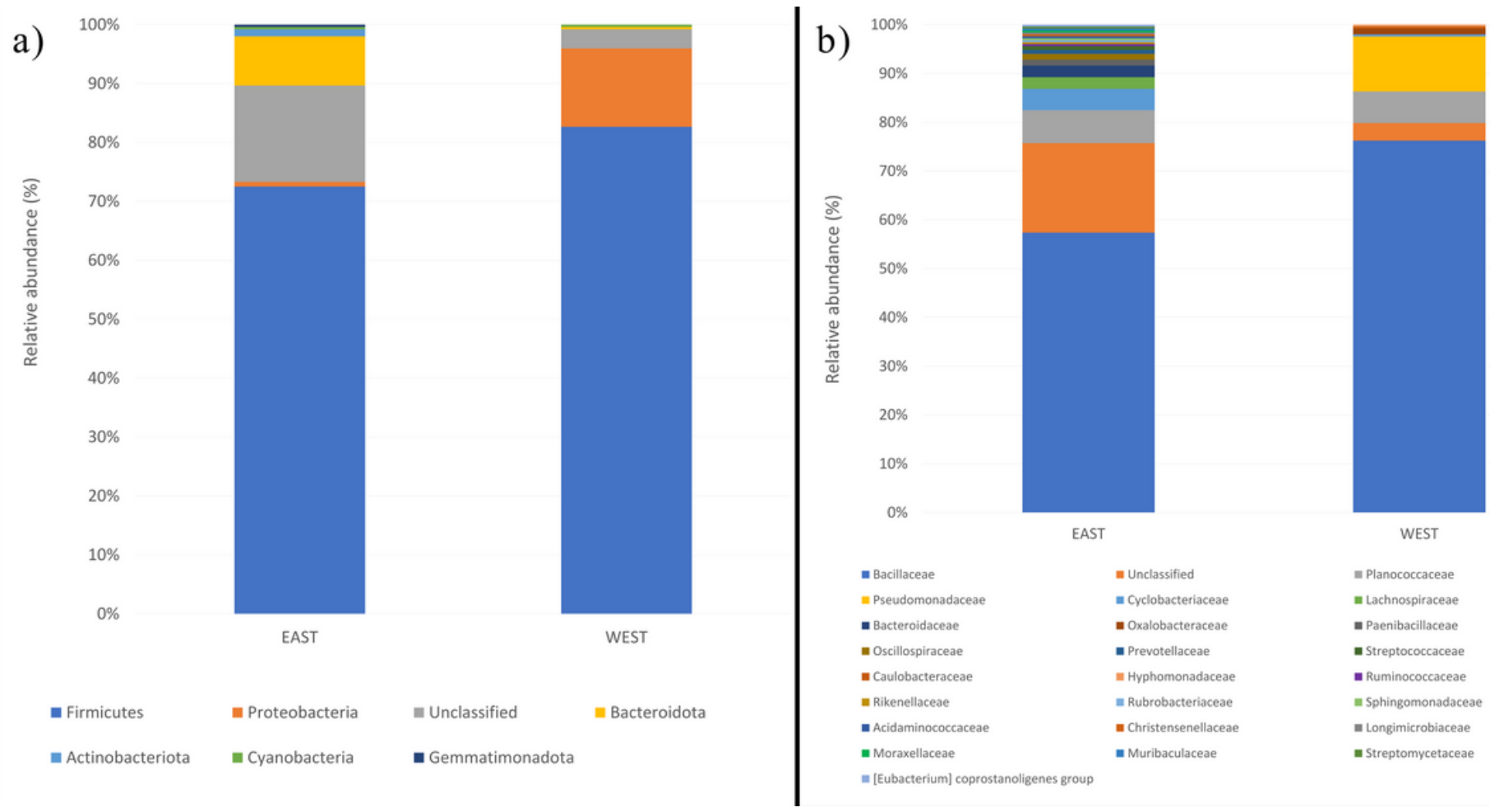

\section{Figure 8}

Relative percentage abundance of bacterial phyla (a) and families (b) found in the east and west walls of the Santa Margherita's cave.

\section{Supplementary Files}

This is a list of supplementary files associated with this preprint. Click to download.

- Supportinformation.docx 